\title{
PENGARUH PENAMBAHAN BUAH NAGA MERAH (Hylocereus costaricensis) TERHADAP MUTU KIMIA PEMPEK IKAN GABUS (Channa striata)
}

\author{
Dodi Tisnaamijaya $^{1}$, Tri Widayatsih ${ }^{2}$, dan Fitra Mulia Jaya ${ }^{2}$ \\ 1) Alumni Fakultas Perikanan Universitas PGRI Palembang \\ 2) Staf Pengajar Fakultas Perikanan Universitas PGRI Palembang \\ Email : perikanan.pgri@gmail.com
}

\begin{abstract}
Abstrak
Pempek adalah salah satu makanan tradisional yang ada di kota Palembang. umumnya berbahan dasar daging ikan giling, tepung tapioka, air dan garam. Pempek ikan Gabus (Channa striata) memiliki kandungan gizi yang cukup tingi, salah satu kandungan yang terdapat dalm pempek ini adalah protein yang cukup tinggi. Kesadaran masyarakat akan pentingnya hidup sehat membuat masyarakat berinofasi membuat olahan makanan yang sehat. Salah satu cara untuk meningktakan pangan yang bernilai gizi tinggi, pangan yang telah ada ditambah dengan bahan makanan lain. Penelitian ini bertujuan untuk mengetahui karakteristik pempek Ikan Gabus (Channa striata) yang ditambah Buah Naga (Hylocereus costaricensis). Rancangan penelitian yang digunakan dalam penelitian ini adalah rancangan acak lengkap (RAL) dengan perlakuan faktor tunggal persentase buah naga yang berbeda. Penelitian ini menggunakan 4 taraf perlakuan dengan 3 kali ulangan. Perlakuan pada penelitian ini yaitu penambahan buah naga merah (Hylocereus costaricensis) dengan komposisi yang berbeda (b/b) yaitu : 0\%, 5\%, 10\%, dan 15\% (dari berat bahan baku) pada pengolahan pempek ikan gabus (Channa striata). Hasil penelitian didapat perlakuan terbaik yaitu perlakuan $\mathrm{D}_{2}$ (Penambahan buah naga $(10 \%)$. hasil uji kimia yaitu : kadar air $61.63 \%$, abu $2.24 \%$, protein $9.84 \%$, lemak $0.91 \%$, karbohidrat $25.33 \%$.
\end{abstract}

Kata Kunci : $\quad$ Pempek, Buah Naga Merah, Uji Proksimat

\begin{abstract}
Pempek is one of the traditional food in Palembang city. generally made from fish meat, tapioca flour, water and salt. Pempek Gabus fish (Channa striata) has a high nutrien, one of the content contained in this pempek is a fairly high protein. Public awareness of the importance of healthy living makes people innovate to make healthy food preparations. One way to increase the food of high nutrient is, the existing food added with of the other food ingredients. This study aims to determine the characteristics of Gabus fish (Channa striata) added with dragon fruit (Hylocereus costaricensis). The research design used in this study was a complete randomized design (RAL) with single factor treatment of different percentage of the dragon fruit. This study used 4 treatment levels with 3 replications. The treatment of this research is the addition of red dragon fruit (Hylocereus costaricensis) with different composition $(b / b)$ that is: $0 \%$, 5\%, $10 \%$, and $15 \%$ (from raw material weight) on the processing Gabus fish (Channa striata). Theresult of this research is the best treatment of $\mathrm{D}_{2}$ (addition of dragon fruit 10\%) with water content $61.63 \%$, ash $2.24 \%$, protein $9.84 \%$, fat $0.91 \%$ and carbohydrate $25.33 \%$.
\end{abstract}

Keywords: Pempek, Red Dragon Fruit, Proximate analysis 


\section{PENDAHULUAN}

Pempek merupakan salah satu makanan khas kota Palembang yang umumnya berbahan dasar daging ikan giling, tepung tapioka, air dan garam. Menurut Karneta (2010), tahapan pengolahan pempek terdiri dari penggilingan daging ikan, pencampuran bahan, pembentukan pempek, dan pemasakan. Pempek memiliki kandungan protein 4,2 g, lemak $1,4 \mathrm{~g}$, karbohidrat 31,6 g, air 61,4 g; abu 1,2 g, kalsium $100 \mathrm{mg}$, fosfor $55 \mathrm{mg}$, besi $3,3 \mathrm{mg}$, vitamin B1 0,03 $\mathrm{mg}$, serat $0,2 \mathrm{~g}$, dan vitamin C 0 mg (Departemen Kesehatan Republik Indonesia, 2004). Pempek dikonsumsi oleh setiap lapisan masyarakat mulai dari anak-anak, remaja hingga dewasa. Pada awalnya pempek dibuat menggunakan daging ikan Belida, namun ketersediaan daging ikan Belida yang semakin sulit didapat, bahan baku daging ikan diganti dengan daging ikan lainnya.

Salah satu ikan yang cocok untuk menjadi bahan dasar pempek adalah ikan Gabus (Channa striata), ikan ini memiliki tekstur daging yang empuk serta kandungan gizi yang cukup tinggi. Menurut Kusmini $d k k$ (2016), ikan Gabus memiiki kandungan protein $20 \mathrm{~g}$, lemak 1,5 g, karbohidrat 0,2 g, mineral 1,3 g, dan air 77 g. Agar kandungan gizi didalam pempek lebih banyak dapat juga ditambahkan dengan bahan lain. Dewasa ini kesadaran masyarakat Indonesia akan pentingnya hidup sehat makin meningkat, hal tersebut dibuktikan semakin banyaknya masyarakat mengkonsumsi makanan yang sehat. Salah satu makanan sehat yang biasa dikonsumsi oleh masyarakat adalah buahbuahan. Buah buahan yang memiliki berbagai macam manfaat dapat kita temui disekitar kita, Dengan mengkonsumsi buah maka kita akan mendapatkan gizi dan menjaga kesehatan kita. Buah juga dapat meningkatkan energi dan kebutuhan vitamin pada tubuh manusia.

Salah satu buah yang saat ini mulai digemari oleh masyarakat adalah buah Naga.Buah Naga adalah buah yang berasal dari Meksiko, Amerika Tengah dan Amerika Selatan. Buah Naga merupakan buah yang unik jika dilihat dari bentuknya yang menyerupai sisik naga sehingga lebih dikenal oleh banyak orang dengan nama Buah Naga (dragon fruit). Kandungan yang terdapat dalam $100 \mathrm{mg}$ Buah Naga adalah protein 0,229 g, lemak 0,61 g, kalsium 6,9 g fosfor 36,1 mg, karbohidrat 11,5 $\mathrm{g}$, vitamin B1 0,28 mg, vitamin B2 $0,045 \mathrm{mg}$, vitamin B3 0,43 mg, vitamin C $9 \mathrm{mg}$, air $83 \mathrm{mg}$ dan serat 0,7 - 0,9 g. (Saparinto dan Rini Susiana, 2016). Berdasarkan kandungan yang terdapat pada buah naga tersebut, Buah Naga dapat dimanfaatkan sebagai bahan tambahan untuk menambah kandungan gizi didalam Pempek. Tujuan penelitian ini adalah untuk mengetahui sifat kimia dan menentukan formulasi kimia terbaik pempek Ikan Gabus (Channa striata) dengan penambahan Buah Naga Merah (Hylocreus costaricensis).

\section{METODE PENELITIAN}

Penelitian ini dilaksanakan dari 28 Oktober sampai 14 Desember 2017 di Workshop Teknologi Pengolahan Hasil Perikanan (WSTPHP) Fakultas Perikanan Universitas PGRI Palembang dan Laboratorium Kimia dan Mikrobiologi Hasil Pertanian Jurusan Teknologi Pertanian Fakultas Pertanian Universitas Sriwijaya Indralaya. Adapun bahan utama atau bahan baku yang digunakan untuk pembuatan pempek adalah daging ikan gabus (Channa striata) dan daging buah naga merah, tepung tapioca, air es dan garam.

Adapun alat-alat yang digunakan dalam pengolahan pempek ini meliputi : baskom, panci, kompor gas, nampan, food processor, blender, timbangan digital. Adapun alat-alat yang digunakan untuk uji kimia olahan pempek berupa alat titrasi, desikator, texture analyzer, colour reader. Penelitian ini menggunakan metode eksperimen dengan rancangan percobaan yang Rancangan Acak Lengkap (RAL) dengan perlakuan faktor tunggal persentase buah naga yang berbeda.Penelitian ini menggunakan 4 taraf perlakuan dengan 3 kali ulangan. Berikut adalah taraf perlakuan dalam penelitian ini.

$\mathrm{D}_{0}$ : Tanpa penambahan buah naga $(0 \%)$

$\mathrm{D}_{1}$ : Penambahan buah naga $(5 \%)$

$\mathrm{D}_{2}$ : Penambahan buah naga $(10 \%)$

$\mathrm{D}_{3}$ : Penambahan buah naga $(15 \%)$

Proses Pengolahan Pempek Ikan Gabus (Channa striata) Dengan Penambahan Konsentrsi Buah Naga Merah (Hylocereus costaricensis). Bahan-bahan yang digunakan dalam proses pengolahan pempek dari Ikan Gabus (Channa striata) yang ditambahkan Buah Naga Merah (Hyloceleus costaricensis) adalah : ikan gabus, tepung sagu, buah naga merah, bawang putih, garam dan air. Adapun tahapan pengolahan pempek ikan gabus dengan penambahan buah naga adalah sebagai berikut:

a. Ikan Gabus (Channa striata) segar dilakukan penyiangan untuk dibuang kepala, isi perut dan kulit, setelah itu dicuci menggunakan air bersih dan dilakukan pemfiletan untuk mendapatkan daging Ikan Gabus, kemudian dilumatkan menggunakan mesin penggiling ikan atau food frocessor. 
b. Daging Ikan Gabus (Channa striata) sebanyak $100 \%$ yang telah dilumatkan di tambahkan garam $2 \%$ dari bahan baku, dan air es $15 \%$ dari bahan baku, lalu homogenkan.

c. Kemudian campurkan daging buah naga yang telah diblender menjadi bubur sesuai perlakuan yaitu $5 \%, 10 \%$, dan $15 \%$.

d. masukkan tepung tapioka $80 \%$ secara bertahap hingga adonan kalis dan dapat dibentuk.

e. Setelah didapat adonan yang homogen, adonan dibentuk menjadi bentuk lenjer atau lenjer dengan berat 28 Gram, panjang $7 \mathrm{~cm}$ dan diameter $2,5 \mathrm{~cm}$.

f. Adoanan pempek yang telah dibentuk kemudian direbus kedalam air yang mendidih selama 15 menit sampai pempek mengapung kepermukaan air.

g. Angkat pempek yang telah matang dan tiriskan.

h. Pempek ikan gabus dengan penambahan Buah Naga kemudian dianalisi secara fisik, kimia, dan sensoris.

Adapun parameter yang diamati dalam penelitian ini meliputi : Analisa proksimat meliputi kadar air metode Gravimetri, (AOAC, 2005) , kadar abu Metode Gravimetri (AOAC, 2005), kadarlemak Metode Soxhlet (AOAC, 2005) dan kadar protein Metode Mikro Kjeldalhl (AOAC, 2005).Analisis yang digunakan meliputi analisis Parametrik, data yang diperoleh disajikan dalam bentuk tabel dan grafik serta dilakukan analisis ragam (ANOVA).Apabila berpengaruh nyata, maka dilanjutkan dengan uji lanjut berdasarkan koefisien keragaman (Hanafiah, 2012).

\section{HASIL DAN PEMBAHASAN}

\section{Analisa Kadar Air}

Kadar air adalah banyaknya kandungan air yang terdapat di dalam sebuah produk pangan yang dinyatakan dalam persen (\%). Kadar air merupakan karakteristik yang sangat penting pada produk pangan seperti pempek karena dapat mempengaruhi tekstur dan umur simpan pempek.Menurut Winanrno, (1977) dalam Febrianto dkk, (2014) Kadar air dalam bahan makanan ikut menentukan kesegaran dan daya awet bahan makanan tersebut. Adapun diagram batang nilai rata - rata kadar air pempek dengan penambahan buah naga dapat dilihat pada Gambar 1.



Gambar 1. Kadar Air Pempek dengan penambahan Buah Naga.

Nilai rata-rata kadar air pempek tertinggi terdapat pada perlakuan $\mathrm{D}_{3}$ (Penambahan Buah Naga Merah $15 \%$ ) dengan nilai rata-rata 63.82 $\%$, sedangkan nilai kadar air terendah terdapat pada perlakuan $\mathrm{D}_{2}$ (Penambahan Buah Naga Merah $10 \%$ ) yaitu $61.68 \%$.

Pada gambar 1 menunjukan bahwa adanya peningkatan kadar air pada pempek. Berdasarkan gambar di atas dapat diketahui bahwa perlakuan penambahan buah naga merah dapat meningkatkan kadar air pada pempek. Penambahan buah naga merah pada pempek dapat meningkatkan kadar air pada pempek, semakin banyak buah naga yang ditambahkan maka semakin tinggi kadar air yang dihasilkan. Menurut Jaya dan Sari (2017) meningkatkny akadar air pada produk erat berhubungan dengan kandungan protein pada produk tersebut yaitu protein memiliki daya air yang tinggi pada sehingga lepasnya air pada saat proses pemasakan dapat berkurang.

Hasil analisis sidik ragammenunjukkan bahwa perlakuan penambahan buah naga merah dengan komposisi yang berbeda memberikan pengaruh tidak nyata terhadap kadar Air yang dihasilkan, karena nilai $\mathrm{F}$ hit $=1.63$ lebih kecil dari F Tabel $0,05=4.07$ dan $0.01=7.59$ maka tidak dilakukan uji lanjut.

\section{Analisa Kadar Abu}

Abu adalah residu organik dari pembakaran bahan-bahan anorganik. Abu sisa pembakaran pada analisis kadar abu menunjukkan banyaknya kandungan zat anorganik dalam produk tersebut, sedangkan yang menguap menunjukkan kandungan zat organik. Biasanya komponen tersebut terdiri dari kalsium, kalium, natrium, besi, mangan, magnesium, dan iodium (Apriansyah, 2015). Adapun diagram batang nilai rata - rata kadar abu pempek dengan penambahan buah naga dapat dilihat pada Gambar 2. 


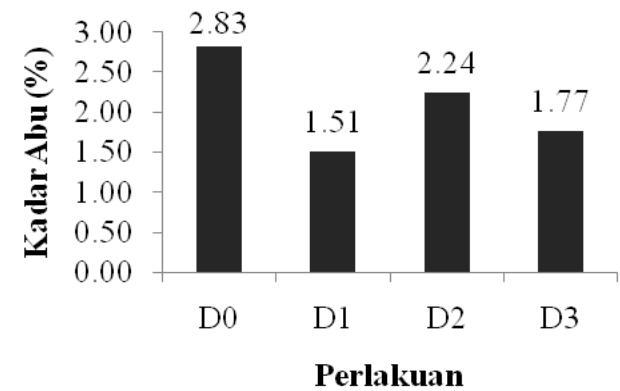

Gambar 2. Abu Pempek dengan penambahan Buah Naga.

Nilai rata-rata kadar abu pempek tertinggi terdapat pada perlakuan $\mathrm{D}_{0}$ (Tanpa Penambahan Buah Naga Merah $0 \%$ ) dengan nilai rata-rata $2.83 \%$, sedangkan nilai kadar air terendah terdapat pada perlakuan $\mathrm{D}_{1}$ (Penambahan Buah Naga Merah $5 \%$ ) yaitu 1.51 $\%$. Hasil analisa sidik ragam menunjukan bahwa perlakuan penambahan buah naga merah dengan komposisi yang berbeda, berbeda nyata terhadap kadar abu oleh karena itu dilakukan uji lanjut Beda Nyata Jujur (BNJ). Adapun hasil uji lanjut Beda Nyata Jujur (BNJ) dapat dilihat pada Tabel 1.

Tabel 1. Uji Lanjut BNJ Terhadap Kadar Abu Pempek

\begin{tabular}{lcc}
\hline Perlakuan & Rerata & $\begin{array}{c}\text { Notasi } \\
\mathbf{5 \%}=\mathbf{0 . 8 9}\end{array}$ \\
\hline D1 $(5 \%)$ & 1.51 & $\mathrm{a}$ \\
$\mathrm{D} 3(15 \%)$ & 1.77 & $\mathrm{a}$ \\
$\mathrm{D} 2(10 \%)$ & 2.24 & $\mathrm{ab}$ \\
$\mathrm{D} 0(0 \%)$ & 2.83 & $\mathrm{~b}$ \\
\hline Keterangan & $\begin{array}{l}\text { Kolom yang diikuti hurup yang sama } \\
\text { menunjukan bahwa perlakuan tidak berbed } \\
\text { nyata }\end{array}$
\end{tabular}

Dari Tabel 1, menunjukan bahwa perlakuan $\mathrm{D}_{0}$ (tanpa penambahan buah naga merah $0 \%$ ) dan perlakuan $\mathrm{D}_{2}$ (Penambahan Buah Naga Merah $10 \%$ ) berbeda nyata dengan perlakuan $\mathrm{D}_{3}$ (Penambhan Buah Naga Merah 15 $\%$ ) dan perlakuan $\mathrm{D}_{1}$ (Penambahan Buah Naga $5 \%$ ). Menurut Sudarmadji et al. (1989) dalam Yuliana (2013), menyatakan bahwa makanan yang berasal dari hewani mengandung kadar abu yang tinggi, hal ini disebabkan oleh kandungan beberapa mineral seperti kalsium, besi dan fosfor. Perlakuan D (Tanpa Penambahan Buah Naga Merah 0 \%) kadar abu lebih tinggi dibandingkan dengan perlakuan lainnya, hal ini dikarenakan kadar air yang yang relatif rendah, sedangkan Pada perlakuan $D_{1}$ (Penambahan Buah Naga Merah $5 \%$ ), $\mathrm{D}_{3}$ ( Penambahan Buah Naga Merah $15 \%$ ), dan $\mathrm{D}_{2}$ (Penambahan Buah Naga Merah $10 \%$ ), kadar abu lebih rendah dari perlakuan $\mathrm{D}_{0}$ (Tanpa
Penambahan Buah Naga Merah $0 \%$ ). Jadi dapat diketahui bahwa dengan adanya penambahan konsentrasi buah naga merah kadar abu juga mengalami penurunan.

\section{Analisa Kadar Lemak}

Lemak merupakan zat makanan yang penting bagi tubuh dan merupakan sumber energi yang lebih efektif dibandingkan dengan karbohidrat dan protein, (Winarno, 1992 dalam Gusriadi, dkk 2014). Lemak memberikan cita rasa dan perbaikan tekstur pada bahan makanan juga sebagai sumber energi dan pelarut bagi vitamin $\mathrm{A}, \mathrm{D}, \mathrm{E}$ dan $\mathrm{K}$. Lemak adalah suatu senyawa biomolekul yang larut pada senyawa organik tertentu dan tidak larut dalam air. Adapun kadar lemak pempek dengan penambahan buah naga dapat dilihat pada Gambar 3.

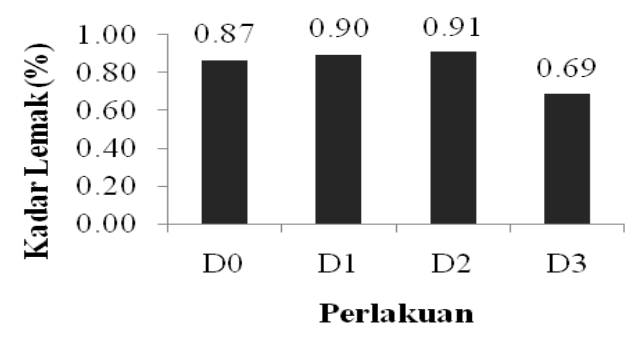

Gambar 3. Nilai Rata - rata Kadar Lemak Pempek Dengan Penambahan Buah Naga.

Nilai rata-rata kadar lemak pempek tertinggi terdapat pada perlakuan $\mathrm{D}_{2}$ (penambahan buah naga $10 \%$ ) dengan nilai rata-rata $0.91 \%$, sedangkan nilai kadar lemak terendah terdapat pada perlakuan $\mathrm{D}_{3}$ (penambahan buah naga $15 \%$ ) yaitu $0.69 \%$. Gambar 3 menunjukkan bahwa perlakuan penambahan buah naga tertinggi $\mathrm{D}_{3}$ (Penambahan buah naga merah $15 \%$ ) memiliki kadar lemak paling rendah. Namun pada perlakuan lain kadar lemak cenderung lebih tinggi. Namun selisih nilai rata-rata kadar lemak pada setiap perlakuan tidak jauh berbeda sehingga kadar lemak tidak berbeda nyata. Hasil analisis sidik ragam menunjukkan bahwa perlakuan penambahan buah naga merah dengan komposisi yang berbeda memberikan pengaruh tidak nyata terhadap kadar lemak yang dihasilkan, karena nilai $\mathrm{F}$ hit $=1.33$ lebih kecil dari F Tabel $0,05=4.07$ dan $0.01=7.59$ maka tidak dilakukan uji lanjut.

\section{Analisa Kadar Protein}

Protein adalah suatu zat makanan yang sangat berperan penting bagi tubuh, disamping berfungsiya sebagai bahan bakar dalam tubuh, protein juga berfungsi sebagai zat pembangun dan pengatur.Protein dapat digunakan sebagai 
sumber energi cadangan apabila keperluan energi tubuh tidak terpenuhi oleh karbohidrat dan lemak. Menurut Winarno, (1997) dalam Apriansyah, (2015). Selain Sebagai zat pembangun dan pengatur, protein merupakan bahan pembentuk jaringan-jaringan baru serta dapat berfungsi untuk mempertahankan jaringan yang telah ada di dalam tubuh manusia. Adapun kadar protein pempek dengan penambahan buah naga dapat dilihat pada Gambar 4 .

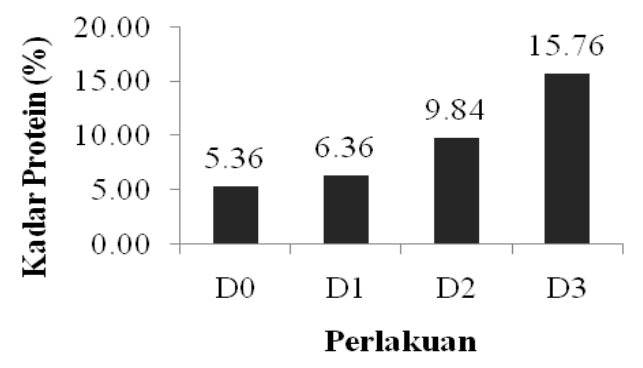

Gambar 4. Kadar Protein Pempek Dengan Penambahan Buah Naga.

Nilai rata-rata kadar protein pempek tertinggi terdapat pada perlakuan $D_{3}$ (Penambahan Buah Naga Merah $15 \%$ ) dengan nilai rata-rata $15.76 \%$, sedangkan nilai kadar protein terendah terdapat pada perlakuan $\mathrm{D}_{0}$ (Tanpa Penambahan Buah Naga Merah $0 \%$ ) yaitu $5.36 \%$. Gambar 4, menunjukkan bahwa penambahan buah naga tertinggi dapat meningkatkan kadar protein pada pempek. Berdasarkan data diatas dapat diketahui bahwa semakin tinggi penambahan buah naga merah maka semakin tinggi kadar protein pada pempek. Hasil analisa sidik ragam menunjukan bahwa perlakuan penambahan buah naga merah dengan komposisi yang berbeda, berbeda nyata terhadap kadar protein, oleh karena itu dilakukan uji lanjut Beda Nyata Jujur (BNJ). Adapun hasil uji lanjut Beda Nyata Jujur (BNJ) dapat dilihat pada Tabel 2 .

Tabel 2. Uji Lanjut BNJ Terhadap Kadar Protein Pempek

\begin{tabular}{lcc}
\hline Perlakuan & Rerata & $\begin{array}{c}\text { Notasi } \\
\mathbf{5 \% = 1 . 8 4}\end{array}$ \\
\hline D0 $(0 \%)$ & 5.36 & $\mathrm{a}$ \\
D1 $(5 \%)$ & 6.36 & $\mathrm{a}$ \\
D2 $(10 \%)$ & 9.84 & $\mathrm{~b}$ \\
D3 $(15 \%)$ & 15.76 & $\mathrm{c}$ \\
\hline Keterangan : Hurup yang diikuti hurup yang sama \\
\multicolumn{3}{c}{ menunjukan bahwa perlakuan tidak berbed } \\
nyata \\
Dari tabel 2, menunjukan bahwa
\end{tabular}
perlakuan $\mathrm{D}_{0}$ (Tanpa Penambahan Buah Naga Merah $0 \%$ ) dan perlakuan $\mathrm{D}_{1}$ (Penambahan Buah Naga Merah $5 \%$ ) berbeda nyata dengan perlakuan $\mathrm{D}_{2}$ (Penambahan Buah Naga Merah 5 $\%$ ) dan perlakuan $\mathrm{D}_{3}$ (Penambahan Buah Naga
Merah $15 \%$ ). Nilai kadar protein pempek setiap perlakuan memiliki nilai berbeda yang disebabkan oleh perbedaan komposisi buah naga merah yang ditambahkan pada pempek yaitu semakin tinggi komposisi buah naga merah yang ditambahkan, maka kadar protein akan semakin tinggi. Hal ini dikarenakan adanya kandungan protein yang terdapat didalam buah naga sebanyak 0,23 g (Rahmawati \& Mahajoeno, 2010).

Selain itu Ikan Gabus memiliki kandungan protein yang cukup tinggi. Menurut Ardianto (2015), menyatakan bahwa ikan gabus mengandung protein cukup tinggi yaitu sebanyak $20 \%$ per 100 gram. Selain itu peningkatan kadar protein pada pempek dengan penambahan Buah Naga Merah hal ini dikarenakan penentuan protein kasar dengan menggunakan metode Kjeldahl, karena pada umumnya metode ini digunakan untuk analisis protein pada makanan. Metode Kjeldahl merupakan metode untuk menentukan kadar protein kasar, karena terikut senyawa $\mathrm{N}$ bukan protein seperti urea, asam nukleat, purin, pirimidin dan sebagainya (Rosaini, dkk. 2015). Prinsip kerja metode Kjeldahl adalah mengubah senyawa organik menjadi anorganik (Usysus, et al, 2009) yaitu senyawa $\mathrm{N}$, sehingga semakin banyak ditambahkannya Buah Naga Merah maka senyawa $\mathrm{N}$ semakin meningkat.

\section{Analisa Kadar Karbohidrat}

Karbohidrat merupakan sumber energi utama bagi manusia. Karbohidrat juga mempunyai peranan penting dalam menentukan karakteristik bahan makanan, misalnya rasa, warna, dan tekstur. Karbohidrat sendiri terdiri atas karbon, hidrogen, dan oksigen. Adapun kadar karbohidtrat pempek dengan penambahan buah naga dapat dilihat pada Gambar 5.

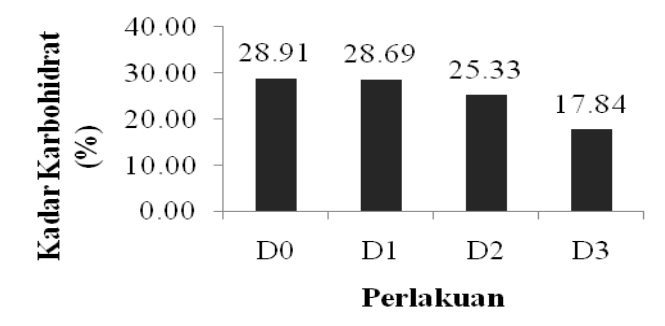

Gambar 5. Kadar Karbohidrat Pempek Dengan Penambahan Buah Naga.

Nilai rata-rata kadar karbohidrat pempek tertinggi terdapat pada perlakuan $\mathrm{D}_{0}$ (Tanpa Penambahan Buah Naga Merah $0 \%$ ) dengan nilai rata-rata $28.91 \%$, sedangkan nilai kadar protein terendah terdapat pada perlakuan $\mathrm{D}_{3}$ (Penambahan Buah Naga Merah $15 \%$ ) yaitu $17.84 \%$. Hasil analisa sidik ragam menunjukan 
bahwa perlakuan penambahan buah naga merah dengan komposisi yang berbeda, berbeda nyata terhadap kadar karbohidrat, oleh karena itu dilakukan uji lanjut Beda Nyata Jujur (BNJ). Adapun hasil uji lanjut Beda Nyata Jujur (BNJ) dapat dilihat pada Tabel 3.

Tabel 3. Uji Lanjut BNJ Terhadap Kadar Karbohidrat Pempek

\begin{tabular}{ccc}
\hline Perlakuan & Rerata & $\mathbf{5 \%}=\mathbf{2 . 8 1}$ \\
\hline D3 $(15 \%)$ & 17.84 & $\mathrm{a}$ \\
D2 $(10 \%)$ & 25.33 & $\mathrm{~b}$ \\
D1 $(5 \%)$ & 28.69 & $\mathrm{c}$ \\
D0 $(0 \%)$ & 28.91 & $\mathrm{c}$ \\
\hline Keterangan : Hurup yang diikuti hurup yang sama \\
menunjukan bahwa perlakuan tidak \\
berbed nyata
\end{tabular}

Dari Tabel 3, menunjukan bahwa perlakuan $\mathrm{D}_{0}$ (Tanpa Penambahan Buah Naga Merah $0 \%$ ) dan perlakuan $\mathrm{D}_{1}$ (Penambahan Buah Naga Merah 5\%) berbeda nyata dengan perlakuan $\mathrm{D}_{2}$ (Penambhan Buah Naga Merah $5 \%$ ) dan perlakuan $\mathrm{D}_{2}$ (Penambahan Buah Naga Merah $10 \%$ ) berbeda nyata dengan perlakuan $\mathrm{D}_{3}$ (Penambahan Buah Naga Merah 15\%). Kadar karbohidrat pempek pada setiap perlakuan memiliki nilai berbeda, semakin banyak buah naga merah ditambahkan maka semakin rendah kadar karbohidrat. Hal ini juga disebabkan oleh karbohidrat seringkali bergabung dengan protein menjadi glikoprotein. Menurut Martoharsono dan Mulyono (1976) dalam Apriansyah (2015), karbohidrat seringkali bergabung dengan senyawa golongan lain seperti protein dengan nama glikoprotein. Sehingga kadar karbohidrat berkurang seiring dengan meningkatanya penambahan konsentrasi buah naga merah.

\section{IV.KESIMPULAN DAN SARAN}

1. Kesimpulan

a. Perlakuan penambahan Buah Naga Merah (Hylocreus costaricensis) terhadap sifat kimia pempek Ikan Gabus (Channa striata) berpengaruh nyata terhadap kadar abu, protein, dan karbohirat, dan berpengaruh tidak nyata kadar air dan lemak

b. Secara umum perlakuan terbaik terdapat pada perlakuan $\mathrm{D}_{2}$ (Penambahan buah naga kadar air $61.69 \%$, abu $2.24 \%$, protein 9.84 $\%$, lemak $0.91 \%$, karbohidrat $25.33 \%$.

\section{Saran}

Perlu dilakukan uji kandungan vitamin terhadap pempek Ikan Gabus (Channa striata) dengan penambahan Buah Naga Merah (Hylocereus costaricensis) .

\section{DAFTAR PUSTAKA}

Apriansyah, E. 2015. Penambahan Daging Ikan Lele Dumbo (Clarias gariepinus) dengan Komposisi yang berbeda terhadap Karakteristik Mi Instan. Skripsi. Fakultas Perikanan Universitas PGRI Palembang. Palembang.

Departemen Kesehatan Republik Indonesia. 2004. Daftar Komposisi Gizi Bahan Makanan. Bhratara Karya Aksara Jakarta.

Febrianto, A. Basito dan Anam, C. 2014. Kajian Karakteristik Fisikokimia dan Sensoris Tortilla Corn Chips dengan Variasi Larutan Alkali pada Proses Nikstamalisasi Jagung. Jurnal Teknosains Pangan. 3(3) : 22 - 34

Jaya, F. M. dan Sari, D, I. 2017. Analisis Kimia Burger Ikan Dengan Penambahan (Clarias gariepinus) Dan Tepung Terigu Dengan Komposisi Yang Berbeda.Jurnal Ilmu-Ilmu Perikanan dan Budidaya Perairan 12 (2) : 42 - 49

Gusriadi, D., Sukmiwati, M dan Dahlia. 2014. Peningkatan Gizi Mi Instan dengan Penambahan Tepung Ikan Patin (Pangasius hypophthalmus). JOM. Hal 1-11

Hanafiah, K.A. 2012. Rancangan Percobaan : Teori dan Aplikasi. Raja Grafindo Persada. Jakarta.

Karneta, R. 2010. Analisis Kelayakan Ekonomi dan Optimasi Formulasi Pempek Lenjer Skala Industri. Jurnal Pembangunan Manusia. 4(3): 264-274.

Kusmuni, Irin. Iriana. dkk. 2016. Budidaya Ikan Gabus. Jakarta: Penebar Swadaya.

Rahmawati, B., \& Mahajoeno, E. (2010). Variasi Morfologi, Isozim dan Kandungan Vitamin C pada Varietas Buah Naga. Jurnal Nusantara Bioscience 7(1) : 35-44

Rosaini, H, Rosalindar, R, Hagramida, V. 2015. Penetapan Kadar Protein Secara Kjeldahl Beberapa Makanan Olahan Kerang Remis (Corbiculla moltkiana Prime.) dari Danau Singkarak. Jurnal Farmasi Higea. 7(2) : 120-127

Yuliana, R. 2013. Karakteristik Bakso Ikan Lele (Clarias batracus) dan Ikan Patin (Pangasius hypophthalmus) dengan Konsentrasi Tepung Tapioka yang Berbeda. Skripsi. Fakultas Perikanan Universitas PGRI Palembang. Palembang. 